\title{
TEN YEARS STUDENT SATISFACTION TRENDS ON THE QUALITY OF EDUCATIONAL PROCESS
}

\author{
Koviljka Banjević ${ }^{1}$ \\ Dragana Gardašević \\ Aleksandra Nastasić ${ }^{3}$
}

Received: March 27, 2020 / Revised: May 20, 2020 / Accepted: June 15, 2020

(C) Association of Economists and Managers of the Balkans, 2020

\begin{abstract}
The success of the Higher Education Institution (HEI) mostly depends on student satisfaction, as satisfied students are the basis of institutional existence, its growth and development. The previous does not mean diminishing other institutional performance factors, but the final goal of all processes is to retain existing students and attract freshmen through continual improvement of student satisfaction. The main objective of this paper is to analyse critically the results of measuring student satisfaction in the College of Professional Studies - Belgrade Polytechnic, in relation to the actions taken to improve the educational process. The study included 56 variables of the educational process and non-teaching support, and until now sample was comprised of 3275 undergraduates. For this paper, the variables of the educational process are separated, and the impact of improvements on student satisfaction is analysed by using appropriate statistical tools. The conclusions of this study may contribute to previous, actual and/or future researches in this field, and may equally serve to other HEIs (that operate in a similar environment) as a basis for enhancing student satisfaction.
\end{abstract}

Keywords: Higher education, Assessment, Improvements.

\section{JEL Classification I23}

kbanjevic@politehnika.edu.rs

College of Professional Studies - Belgrade Polytechnic, Katarine Ambrozić 3, Zvezdara, Belgrade, Serbia College of Professional Studies - Belgrade Polytechnic, Katarine Ambrozić 3, Zvezdara, Belgrade, Serbia College of Professional Studies - Belgrade Polytechnic, Katarine Ambrozić 3, Zvezdara, Belgrade, Serbia 


\section{INTRODUCTION}

Over the last decades, the European HE systems were faced with the number of challenges. Consequently, many of European countries implemented the concept of "New Public Management" that implied to transition on the market-based principles. For many HE systems, the new context meant the introduction of the quality management principles - outputs evaluation in relation to inputs; performance appraisal; quality assurance; and external audit (Van Ameijde, Nelson, Billsberry, \& Van Meurs, 2009; Lynch, 2014; Banjević, Nastasić, \& Rošulj, 2019). In the moment of joining Bologna Process, Serbian Government set up the "new" national regulations, in general, based on the quality management principles.

Increasingly, HEIs have perceived that HE could be regarded as a business-like service industry, and they are beginning to focus more on meeting and exceeding the needs and expectations of their students (Gruber, Fuß, Voss, \& Gläser-Zikuda, 2010). Therefore, the HEIs shall monitor, measure and analyse student satisfaction to proactively improve all aspects of HE quality (Harvey, 1995; Aldridge \& Rowley, 1998; Douglas \& Douglas, 2006, p. 6), student wellbeing, institutional image and performance (James et al., 1999). Student satisfaction is a personal, subjective, shortterm, overall attitude resulting from the students' evaluation of educational experience, services and facilities (Athiyaman, 1997; Elliott \& Healy, 2001; Marzo-Navarro et al., 2005; Weerasinghe, Lalitha \& Fernando, 2017). As a complex and multi-dimensional (Hartman \& Schmidt, 1995), student satisfaction effects on students' commitment, loyalty, academic performances, enrolment and retention (Athiyaman, 1997; Elliott \& Healy, 2001; Helgesen \& Nesset, 2007; Nastasić, Banjević, Gardašević, 2019). Student satisfaction is dynamic and based not only on service quality perceptions, but also on personal and situational factors and price (Zeithaml et al., 2008; Gruber, Fuß, Voss, \& Gläser-Zikuda, 2010).

Taking into account the new circumstances in European and national HE area, in 2002 the Belgrade Polytechnic began the process of establishing Quality Management System (QMS). The system according to ISO 9001:2008 was implemented in 2009, and certified by Management Systems Certification Bodies - YUQS and IQNet. The recertification in accordance with SRPS ISO 9001:2015 was done in 2018. Regarding other documented processes, the established QMS involved a continual appraisal of institutional performance indicators, including measuring student satisfaction with the quality of the institution. The institutional quality parameters were defined according to national standards for self-evaluation, established QMS, and experiences of other national and European HEIs. In this sense, the process of evaluation of the student satisfaction with the quality of institution involves the measuring of 13 parameters that are classified in the two clusters - educational process and non-teaching support.

Considering the amount of data that were obtained until now, this paper presents the study based on a survey of undergraduate student satisfaction with the educational process during the tenyear period (2008/2009-2018/2019) at the Belgrade Polytechnic. The data were collected annually until the 2013/2014 academic year, and after that every second year. The individual satisfaction questions were grouped into three parameters affecting overall satisfaction with the educational process - study programme, teaching process and teaching staff. Each of these parameters consists of several variables that analyse it in detail. Additionally, the paper shows trends on student satisfaction in relation to implemented improvement actions during the observed period. 


\section{ANALYSIS OF STUDENT SATISFACTION WITH EDUCATIONAL PROCESS}

\subsection{Methodology and reliability statistics}

The survey strategy was based on quantitative and qualitative methods. In assessing student satisfaction with 16 variables of the educational process, a five-point Likert scale was used, ranging from 1 ("Dissatisfied") to 5 ("Extremely satisfied"). This bipolar scaling method measured either positive or negative response to a statement. In addition, the survey included items related to respondents' demographics, such as the year of evaluation, study programme, the year of study. The survey was sent to all senior students having 48 or more credits hours, i.e. to all undergraduate students of the second and third year of study. The study gathered 3,275 respondents during the 2008/2009-2018/2019 period. Overall, the response rates ranged from 17,47\% (in the 2011/2012) and $47,18 \%$ (in the $2008 / 2009$ ) for the ten-year period (Table 1).

Table 1. The amount of sample size per academic year

\begin{tabular}{|c|c|c|c|c|c|}
\hline $\begin{array}{c}\text { Academic } \\
\text { year }\end{array}$ & Population & $\begin{array}{c}\text { Sample } \\
\text { size }\end{array}$ & \% & $\begin{array}{c}\text { Sample size needed } \\
\text { for 95\% confidence } \\
\text { level and 5 CI }\end{array}$ & $\begin{array}{c}\text { CI (Confidence } \\
\text { interval) }\end{array}$ \\
\hline $2008 / 2009$ & 2090 & 986 & 47,18 & 325 & 2,27 \\
\hline $2009 / 2010$ & 1256 & 368 & 29,30 & 294 & 4,30 \\
\hline $2010 / 2011$ & 1437 & 387 & 36,93 & 303 & 4,27 \\
\hline $2011 / 2012$ & 2186 & 382 & 17,47 & 327 & 4,56 \\
\hline $2012 / 2013$ & 1391 & 406 & 29,21 & 301 & 4,09 \\
\hline $2013 / 2014$ & 1377 & 305 & 22,15 & 301 & 4,95 \\
\hline $2015 / 2016$ & 452 & 211 & 46,68 & 208 & 4,93 \\
\hline $2018 / 2019$ & 731 & 230 & 31,46 & 252 & 5,35 \\
\hline
\end{tabular}

Source: Authors

The changes in population size were consequences of modification in defining target groups - in terms of the studying year, and change in the number of enrolled students. As the survey was carried out every year, respectively every second year, a certain number of students assessed their satisfaction more than once. This approach enables the monitoring of student satisfaction after the implementation of improvement actions.

The analysis included descriptive statistics, a comparison of the measures of central tendency and satisfaction trends on the parameters of educational process, as well as research into the correlation of satisfaction scores with the relevant parameters that describe the educational process (over the years).

Table 2. Reliability Statistics

\begin{tabular}{|c|c|c|c|}
\hline $\begin{array}{c}\text { Parameter of the } \\
\text { educational process }\end{array}$ & Cronbach's Alpha & $\begin{array}{c}\text { Cronbach's Alpha } \\
\text { Based on Standardized } \\
\text { Items }\end{array}$ & N of Items \\
\hline Studying programme &, 794 &, 796 & 4 \\
\hline Teaching Process &, 843 &, 843 & 8 \\
\hline Teaching Staff &, 770 &, 773 & 3 \\
\hline
\end{tabular}

Source: Authors 
The variables for each parameter were tested for internal consistency using the Cronbach's alpha reliability coefficient (Table 2):

The measured coefficients range from 0,77 to 0,84 , so we conclude that good reliability of the measuring scale is fulfilled (Henson, 2001). The highest reliability of the measuring scale is among the variables of the "Teaching Process" parameter $(\alpha=0,84)$, while the lowest is among the variables describing the "Teaching Staff"' parameter $(\alpha=0,77)$.

\subsection{Results Analysis}

To consider the impact of introduced improvements, trend lines were created for the parameters of educational process. Figure 1 refers to a positive trend in all three cases, with Pearson's coefficient of correlation $0,82,0,81,0,88$, respectively, showing the strong positive correlation between parameters of educational process and actions introduced in each academic year.

Study programme

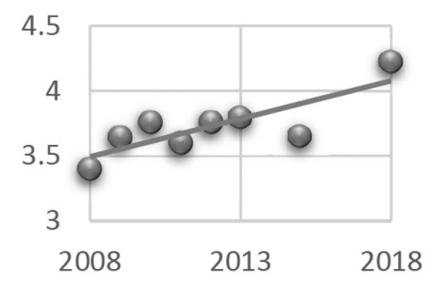

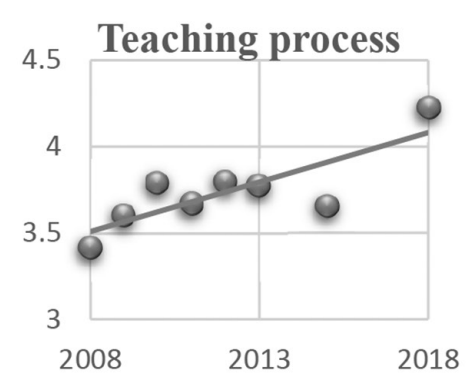

Teaching staff

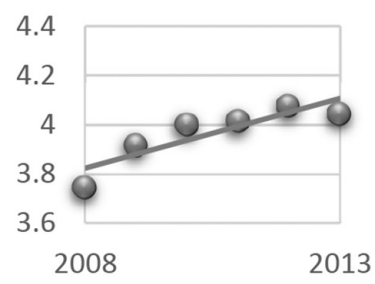

Figure 1. Trend lines for the parameters of educational process

Source: Authors

The improvement actions (Table 3) were introduced between every two evaluation cycles, therefore the satisfaction rating was also based on those implemented actions. The third column (Table 3) refers to depended variable for which action was introduced. Table 3 presents only distinctive improvements, it doesn't cover actions that carry out from time to time, such as development of new study programmes, academic staff development, improvement of library and equipment resources, etc.

Table 3. Introduced improvement actions

\begin{tabular}{|c|l|c|}
\hline Academic year & The introduced improvement actions & $\begin{array}{c}\text { Related to } \\
\text { variable(s) }\end{array}$ \\
\hline \multirow{2}{*}{$\mathbf{2 0 0 8 / 2 0 0 9}$} & $\begin{array}{l}\text { Measures related to academic staff in the cases of unrealized teacher } \\
\text { activities }\end{array}$ & V14 \\
\hline \multirow{2}{*}{$\mathbf{2 0 0 9 / 2 0 1 0}$} & The Physics and Metrology laboratory was established & V2, V11, V12 \\
\cline { 2 - 3 } & The monitoring of lectures realisation & V14-16 \\
\cline { 2 - 3 } & $\begin{array}{l}\text { Improvement of the pre-entry tests in order to enhance the process of } \\
\text { freshmen selection }\end{array}$ & V4 \\
\cline { 2 - 3 } & $\begin{array}{l}\text { Improvement of the student information service by introducing } \\
\text { detailed course catalogue }\end{array}$ & V1, V7 \\
\cline { 2 - 3 } & The Moodle Platform was implemented & V2-4 \\
\hline
\end{tabular}




\begin{tabular}{|c|c|c|}
\hline Academic year & The introduced improvement actions & $\begin{array}{r}\text { Related to } \\
\text { variable(s) }\end{array}$ \\
\hline \multirow{7}{*}{ 2010/2011 } & $\begin{array}{l}\text { The specific software "Shoemaster Leathergoods" at Department of } \\
\text { Design was implemented }\end{array}$ & V3-4 \\
\hline & Improvement of the availability of e-educational materials & V4 \\
\hline & $\begin{array}{l}\text { The process of selection of educational centres in business sector was } \\
\text { formalised, and the collaboration among institution and organisations } \\
\text { was enhanced }\end{array}$ & $\mathrm{V} 3$ \\
\hline & $\begin{array}{l}\text { The student participation at conferences, exhibitions, and similar } \\
\text { events }\end{array}$ & $\begin{array}{l}\text { V2-3, V9, } \\
\text { V11-13 }\end{array}$ \\
\hline & $\begin{array}{l}\text { The evaluation of professional and pedagogical aspects of teacher } \\
\text { works }\end{array}$ & V14-16 \\
\hline & The implementation of the system based on learning outcomes & V2-4 \\
\hline & $\begin{array}{l}\text { Access to the national/international databases of e-publications } \\
\text { (journals and books) for students and teachers }\end{array}$ & V4 \\
\hline \multirow[t]{2}{*}{ 2011/2012 } & $\begin{array}{l}\text { Enhancement of evaluation of students competences by introducing } \\
\text { feedback from students and employers }\end{array}$ & V2-3, V11-12 \\
\hline & The trainings for the students with lower level of pre-education & $\mathrm{V} 2-3$ \\
\hline \multirow{2}{*}{ 2012/2013 } & $\begin{array}{l}\text { The process of annual reviewing and updating the contents of single } \\
\text { courses }\end{array}$ & $\mathrm{V} 2-4, \mathrm{~V} 7-12$ \\
\hline & $\begin{array}{l}\text { The studio of leather design, laboratory of graphic engineering and } \\
\text { the photo-studio were established }\end{array}$ & $\mathrm{V} 2-4, \mathrm{~V} 8-12$ \\
\hline \multirow{3}{*}{ 2013/2014 } & The Instructions for creating student vocational papers & $\mathrm{V} 2-3$ \\
\hline & The first agreements of international collaboration & V2-4 \\
\hline & The laboratory of work environment analyses was established & $\mathrm{V} 2-4, \mathrm{~V} 8-12$ \\
\hline \multirow[b]{2}{*}{$2014 / 2015$} & One more computer laboratory was established & V2-4, V8-12 \\
\hline & $\begin{array}{l}\text { Enhancement the teaching methods by using video tutorials at several } \\
\text { courses }\end{array}$ & V4 \\
\hline \multirow{2}{*}{ 2015/2016 } & $\begin{array}{l}\text { The first study visits for academic staff, to Program Countries, } \\
\text { through Erasmus+ Project }\end{array}$ & V8-10, V16 \\
\hline & $\begin{array}{l}\text { The training of academic staff related to strengthening the didactic } \\
\text { skills }\end{array}$ & V14-16 \\
\hline \multirow{4}{*}{ 2016/2017 } & $\begin{array}{l}\text { Improvements of the teaching methods by applying adaptive } \\
\text { technologies, and reversible design and engineering }\end{array}$ & $\mathrm{V} 3-4, \mathrm{~V} 8-13$ \\
\hline & The blended learning at several courses & V2-4 \\
\hline & $\begin{array}{l}\text { The study process was enhanced by introducing application } \\
\text { "'e-student", }\end{array}$ & V1 \\
\hline & $\begin{array}{l}\text { The first study visits for students to Program Country through } \\
\text { Erasmus+ project }\end{array}$ & V2-3, V11-12 \\
\hline \multirow{2}{*}{$2017 / 2018$} & $\begin{array}{l}\text { The laboratory of waste analyses was established (supported by } \\
\text { Erasmus+ project) }\end{array}$ & V2-4, V8-12 \\
\hline & $\begin{array}{l}\text { Strengthening the teacher competences by international mobility } \\
\text { program (Erasmus+ project KA107) }\end{array}$ & V4, V16 \\
\hline 2018/2019 & $\begin{array}{l}\text { The students and teachers' mobility programmes through Erasmus + } \\
\text { KA103 and KA107 projects }\end{array}$ & $\begin{array}{l}\text { V2-4, V11- } \\
12, \text { V16 }\end{array}$ \\
\hline
\end{tabular}

Source: Documentation of the Belgrade Polytechnic 
The implemented actions indicate commitment of the Belgrade Polytechnic to continual improvements. To analyse the effects of these improvements in detail the mean values for single variables were calculated (Table 4). Table presents mean values and the number of respondents $(\mathrm{N})$ of the 10 -year student satisfaction surveys with the quality of the educational process, sorted by academic year. Note that the mean values of some variables are missed, because they were changed, or removed, or added in the certain year.

Table 4. Mean of the variables of educational process

\begin{tabular}{|c|c|c|c|c|c|c|c|c|}
\hline & $\begin{array}{l}2008 / \\
2009\end{array}$ & $\begin{array}{l}2009 / \\
2010\end{array}$ & $\begin{array}{l}2010 / \\
2011\end{array}$ & $\begin{array}{l}2011 / \\
2012\end{array}$ & $\begin{array}{l}2012 / \\
2013\end{array}$ & $\begin{array}{l}2013 / \\
2014\end{array}$ & $\begin{array}{l}2015 / \\
2016\end{array}$ & $\begin{array}{l}2018 / \\
2019\end{array}$ \\
\hline \multicolumn{9}{|c|}{ Variables of study programme (mean/ number of respondents) } \\
\hline \multirow{2}{*}{$\begin{array}{l}\text { V1- Availability of } \\
\text { information about the } \\
\text { study programme }\end{array}$} & 3,53 & 3,66 & 3,76 & 3,77 & 3,97 & 4,07 & 3,91 & 4,64 \\
\hline & 971 & 364 & 385 & 377 & 402 & 304 & 211 & 257 \\
\hline \multirow{2}{*}{$\begin{array}{l}\text { V2-Acquiring general } \\
\text { competences }\end{array}$} & 3,45 & 3,69 & 3,83 & 3,67 & 3,86 & 3,86 & 3,67 & 4,08 \\
\hline & 975 & 364 & 384 & 376 & 404 & 305 & 208 & 259 \\
\hline \multirow{2}{*}{$\begin{array}{l}\text { V3 -Acquiring } \\
\text { professional competences }\end{array}$} & 3,24 & 3,62 & 3,73 & 3,58 & 3,74 & 3,78 & 3,52 & 3,98 \\
\hline & 967 & 365 & 381 & 374 & 401 & 305 & 209 & 263 \\
\hline \multirow{2}{*}{ V4 - Curriculum design } & 3,35 & 3,59 & 3,70 & 3,38 & 3,45 & 3,46 & 3,50 & / \\
\hline & 965 & 365 & 383 & 375 & 397 & 303 & 208 & / \\
\hline \multicolumn{9}{|c|}{ Variables of teaching process (mean/ number of respondents) } \\
\hline \multirow{2}{*}{$\begin{array}{l}\text { V5-Availability of } \\
\text { timetable in timely } \\
\text { manner }\end{array}$} & 3,74 & 3,91 & 4,08 & 3,95 & 4,02 & 4,02 & 1 & 4,30 \\
\hline & 972 & 366 & 384 & 278 & 402 & 305 & 1 & 257 \\
\hline \multirow{2}{*}{$\begin{array}{l}\text { V6-Fulfilment of student } \\
\text { expectations with } \\
\text { timetable }\end{array}$} & 3,44 & 3,42 & 3,56 & 3,41 & 3,47 & 3,52 & 3,59 & 1 \\
\hline & 968 & 364 & 383 & 378 & 404 & 305 & 211 & I \\
\hline \multirow{2}{*}{$\begin{array}{l}\text { V7- Availability of } \\
\text { information about each } \\
\text { course in timely manner }\end{array}$} & 3,68 & 4,06 & 4,03 & 3,89 & 4,12 & 4,04 & 1 & 1 \\
\hline & 964 & 365 & 383 & 377 & 404 & 303 & 1 & 1 \\
\hline \multirow{2}{*}{$\begin{array}{l}\text { V8 - Interactivity of } \\
\text { lectures }\end{array}$} & 3,38 & 3,65 & 3,82 & 3,76 & 3,84 & 3,87 & 3,78 & 4,36 \\
\hline & 974 & 366 & 384 & 377 & 403 & 305 & 209 & 264 \\
\hline \multirow{2}{*}{$\begin{array}{l}\text { V9-Opportunity of } \\
\text { creativity development }\end{array}$} & 3,20 & 3,35 & 3,63 & 3,43 & 3,59 & 3,55 & 3,48 & 4,19 \\
\hline & 968 & 367 & 382 & 377 & 402 & 305 & 206 & 258 \\
\hline \multirow{2}{*}{$\begin{array}{l}\text { V10- Examples from } \\
\text { practice are good and } \\
\text { illustrative }\end{array}$} & 3,26 & 3,45 & 3,73 & 3,67 & 3,74 & 3,63 & 3,69 & 4,30 \\
\hline & 959 & 365 & 383 & 375 & 404 & 305 & 208 & 260 \\
\hline \multirow{2}{*}{$\begin{array}{l}\text { V11-Teamwork skills } \\
\text { development }\end{array}$} & 3,24 & 3,40 & 3,61 & 3,61 & 3,71 & 3,65 & 3,73 & 4,05 \\
\hline & 968 & 366 & 383 & 375 & 403 & 303 & 211 & 260 \\
\hline \multirow{2}{*}{$\begin{array}{l}\text { V12-Ability to perform } \\
\text { tasks individually }\end{array}$} & 3,34 & 3,56 & 3,83 & 3,72 & 3,86 & 3,89 & 3,87 & 4,42 \\
\hline & 962 & 366 & 383 & 374 & 402 & 300 & 210 & 262 \\
\hline \multirow{2}{*}{$\begin{array}{l}\text { V13-Participation in } \\
\text { professional and artistic } \\
\text { projects within the study } \\
\text { programme }\end{array}$} & 1 & I & I & 1 & 1 & I & 3,22 & 3,84 \\
\hline & I & I & 1. & 1 & I & I & 207 & 261 \\
\hline
\end{tabular}




\begin{tabular}{|l|c|c|c|c|c|c|c|c|c|c|}
\cline { 2 - 9 } \multicolumn{1}{c|}{} & $\begin{array}{r}\mathbf{2 0 0 8 /} \\
\mathbf{2 0 0 9}\end{array}$ & $\begin{array}{c}\mathbf{2 0 0 9 /} \\
\mathbf{2 0 1 0}\end{array}$ & $\begin{array}{c}\mathbf{2 0 1 0 /} \\
\mathbf{2 0 1 1}\end{array}$ & $\begin{array}{c}\mathbf{2 0 1 1 /} \\
\mathbf{2 0 1 2}\end{array}$ & $\begin{array}{c}\mathbf{2 0 1 2 /} \\
\mathbf{2 0 1 3}\end{array}$ & $\begin{array}{c}\mathbf{2 0 1 3 /} \\
\mathbf{2 0 1 4}\end{array}$ & $\begin{array}{c}\mathbf{2 0 1 5 /} \\
\mathbf{2 0 1 6}\end{array}$ & $\begin{array}{c}\mathbf{2 0 1 8 /} \\
\mathbf{2 0 1 9}\end{array}$ \\
\hline
\end{tabular}

Source: Authors

The students expressed the lowest level of satisfaction with single variables in the 2008/2009 academic year. In the following years, the levels of student satisfaction were gradually increased, except in the cases of the variables "Curriculum design" and "Fulfilment of student expectations with timetable". Besides taken improvement actions, there weren't significant differences in the mean values of "Curriculum design" during the 10 years. This could be explained by the fact that students had information about improvements but they didn't experience them. The characteristic of these improvements is in the time of introducing - before the beginning of lectures in the academic year. The students who attended the course weren't obligated to do it again, and a new generation of students didn't have previous experience with a course. However, the enhancements of satisfaction were noticed in other variables related to "Curriculum design", such as: "Acquiring general competences", "Acquiring professional competences", "Interactivity of lectures", 'Opportunity of creativity development", 'Teamwork skills development", "Ability to perform tasks individually".

Table 3 shows that there weren't any actions directed to variable 'Fulfilment of student expectations with timetable", thus the obtained mean values of satisfaction were expected, i.e. there weren't significant differences among levels of satisfaction during the 10 years. The absence of improvements didn't mean that this variable was important, however it was a consequence of other limiting factors the Belgrade Polytechnic was faced with.

If we look at variables "Availability of information about the study programme" (V1) and "Availability of timetable in timely manner" (V5) there was only one action related to the first variable, but none in the second case. But the positive changes in the level of student satisfaction couldn't be negligible ( $V 1$ from $M=3,53$ to $M=4,64$; and V5 from $M=3,74$ to $M=4,30$ ). The Academic calendar, including timetable, as well as a detailed course catalogue, are always available at the same time before beginning the academic year. The positive trends in student satisfaction with observed variables were probably the effect of changes in information services - from "paper" form to e-student.

The variables - 'Interactivity of lectures", '’opportunity of creativity development", '"Examples from practice are good and illustrative", "Teamwork skills development" and 'Ability to perform tasks individually", refer to significant continual increase of the student satisfaction during the observed period (around one point between the first and last measuring). Since the 2010/2011 academic year, the improvement actions, which were directly or indirectly related to these variables, have been introduced. The mean values of student satisfaction with mentioned variables indicate that students perceived the introduced improvements. 
While there were just a few actions that directly targeted variables of "Teaching staff" parameter (Table 3), the mean values (Table 4) indicate a slight increase in student satisfaction. As teaching staff was actively involved in the implementation of all considered actions, consequently, without direct intention, the variables related to this parameter were improved, and that had positive effect on student satisfaction.

To confirm the previous considerations, the correlation test among parameters of educational process was done (Table 5).

Table 5. Correlations among parameters of educational process

\begin{tabular}{|c|c|c|c|c|c|}
\hline \multicolumn{3}{|c|}{ Control Parameters } & \multirow{2}{*}{$\begin{array}{c}\begin{array}{c}\text { Quality } \\
\text { of the study } \\
\text { programme }\end{array} \\
1,000 \\
\end{array}$} & \multirow{2}{*}{$\begin{array}{c}\begin{array}{c}\text { Quality of the } \\
\text { teaching process }\end{array} \\
, 716\end{array}$} & \multirow{2}{*}{$\begin{array}{l}\text { Quality of the } \\
\text { teaching stuff }\end{array}$} \\
\hline \multirow{9}{*}{ 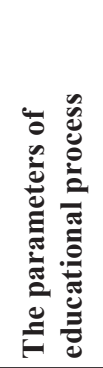 } & \multirow{3}{*}{$\begin{array}{l}\text { Quality of } \\
\text { the study } \\
\text { programme }\end{array}$} & Correlation & & & \\
\hline & & Significance & & , 000 & ,000 \\
\hline & & $\mathrm{df}$ & 0 & 3246 & 3246 \\
\hline & \multirow{3}{*}{$\begin{array}{l}\text { Quality of the } \\
\text { teaching process }\end{array}$} & Correlation & ,716 & 1,000 & 625 \\
\hline & & Significance &, 000 &. &, 000 \\
\hline & & $\mathrm{df}$ & 3246 & 0 & 3246 \\
\hline & \multirow{3}{*}{$\begin{array}{l}\text { Quality of the } \\
\text { teaching stuff }\end{array}$} & Correlation & ,556 & ,625 & 1,000 \\
\hline & & Significance &, 000 &, 000 &, 000 \\
\hline & & $\mathrm{df}$ & 3246 & 3246 & 0 \\
\hline
\end{tabular}

The partial correlation (Table 5) shows a positive moderate correlation among the parameters of educational process, within a range of 0,556-0,716. The greatest correlation is between the "Quality of study programme" and the "Quality of the teaching process" (positive strong, $r=0,716$ ), which means that a change of the satisfaction in one parameter will cause a modification of the satisfaction in other parameter in the same direction. On the other hand, the smallest correlation, yet positively moderate, is between the "Quality of the teaching staff" and the "Quality of the study programme" $(r=0,556)$, in a way that the better quality of teaching stuff implies a slight increase of student satisfaction with the quality of the study programme, and vice versa. The significance level of all results is at 0,01 , which means that only 0,01 chances are presented that our expectations may not be accepted or rejected, i.e. there are $90 \%$ chances of our expectations to be accepted. Based on these results and considerations related to Table 4, we can assume that appropriate improvement of one variable of the educational process leads to an increase of satisfaction with the other two parameters.

\section{CONCLUSION}

Many authors have studied the field of student satisfaction, from different aspects and in relation to the numerous factors. The most of studies refer to the conclusion that variables of the educational process have a great impact on student satisfaction. A few things usually stand out: "The students are typically satisfied when they feel supported by their institution and experience a diverse and stimulating learning experience, that helps them advance their career goals (Global Student Satisfaction Report, 2019, p.10).”

The findings of our study show that the majority of the respondents were very satisfied with the proposed educational parameters. Moreover, the introduced improvements resulted in a positive trend of student satisfaction with parameters of educational process, regard to the observed ten- 
year period. In this period, most of the variables had increasing value, up to one mark. Perhaps, the most important finding is related to positive (moderate to strong) correlation among the parameters of educational process. Detailed correlation and regression analysis with all variables of educational process could be the subject of some future research. Additionally, we collected the great amount of data that could be a good resource for the next studies, such as the impact of improvement action on single variables; the relationship between student satisfaction and other parameters; etc.

The presented results and improvement actions could be helpful for HEIs that operate in a similar environment like this one in Serbia.

\section{ACKNOWLEDGMENT}

This study was supported by the College of Professional Studies - Belgrade Polytechnic.

\section{REFERENCES}

Aldridge, S. and Rowley, J. (1998). Measuring customer satisfaction in higher education. Quality Assurance in Education, 6(4), 197-204.

Athiyaman, A. (1997). Linking Student Satisfaction and Service Quality Perceptions: The Case of University Education. European Journal of Marketing, 31(7), 528-540.

Banjević, K., Nastasić, A., \& Rošulj, D. (2019), Liderstvo u funkciji budućnosti visokoškolskih ustanova, Information Technologies for e-Education. Paper presented at XI International Scientific-Professional Conference ITEO 2019, Aperion University, Banja Luka, December, 6.-7, 2019 (pp. 141-147). Banja Luka: Panevropski Univerzitet 'Aperion".

Douglas, J. and Douglas, A. (2006), Evaluating teaching quality. Quality in Higher Education, 12(1), 3-12.

Elliott, K. M. and Healy, M. A. (2001). Key Factors Influencing Student Satisfaction Related to Recruitment and Retention. Journal of Marketing for Higher Education, 10(4), 1-11.

Global Student Satisfaction Awards, Student Satisfaction - A 2019 Global Overview, Studyportals, 2019, https://studyportals.com/intelligence/global-student-satisfaction-2019/ p. 10.

Gruber, T., Fuß, S., Voss, R. and Gläser-Zikuda, M. (2010), Examining student satisfaction with higher education services: Using a new measurement tool, International Journal of Public Sector Management, 23(2), 105-123. https://doi.org/10.1108/09513551011022474

Hartman, D. E. and Schmidt, S. L. (1995). Understanding Student/Alumni Satisfaction from a Consumer's Perspective: The Effects of Institutional Performance and Program Outcomes. Research in Higher Education, 36(2), 197-217.

Harvey, L. (1995). Student Satisfaction. The New Review of Academic Librarianship, 1, 161-173.

Helgesen, Ø. and Nesset, E. (2007). Images, Satisfaction and Antecedents: Drivers of Student Loyalty? A Case Study of a Norwegian University College. Corporate Reputation Review, 10, 38-59. doi: 10.1057/palgrave.crr.1550037

Henson, R. K. (2001). Understanding internal consistency reliability estimates: A conceptual primer on coefficient alpha. Measurement and Evaluation in Counselling and Development, 34, 177-189.

James, R., Baldwin, G. \& McInnis, C. (1999). Which University? The Factors Influencing the Choices of Prospective Undergraduates. Melbourne: University of Melbourne, Centre for the Study of Higher Education.

Lynch, K. (In Press) "New managerialism" in education: the organisational form of neoliberalism, Open Democracy. https://www.opendemocracy.net/en/new-managerialism-in-education-organisational-form-of-neoliberalism/ 
Marzo-Navarro, M., Iglesias, M. P. \& Torres, P. R. (2005). Measuring Customer Satisfaction in Summer Courses. Quality Assurance in Education, 13(1), 53-65.

Nastasić, A., Banjević, K., Gardašević, D. (2019). Student Satisfaction as a Performance Indicator of Higher Education Institution. Journal of Innovative Business and Management, 11(2), 67-76. DOI: 10.32015/JIBM/2019-11-2-8.

Van Ameijde, D. J. J., Nelson, C. P., Billsberry, J, \& Van Meurs, N. (2009), Improving Leadership in Higher Education Institutions: A Distributed Perspective. Higher Education, 58(6), 763779 .

Weerasinghe, I. S., Lalitha, R., \& Fernando, S. (2017). Students' Satisfaction in Higher Education Literature Review. American Journal of Educational Research, 5(5), 533-539.

Zeithaml, V. A., M. J. Bitner, \& D. D. Gremler (2008), Services Marketing - Integrating Customer Focus Across the Firm", 5th Edition. Boston: McGraw Hill.

\section{ADDITIONAL READING}

Regulation on standards for self-evaluation and quality assessment of higher education institutions and study program. National Entity for Accreditation and Quality Assurance in Higher Education in Serbia - NEAQA, https://www.nat.rs/en/self-evaluation/ 